\title{
ECONOMICS OF TOMATO MARKETING IN ASHANTI REGION, GHANA
}

\author{
Camillus Abawiera Wongnaa, Stephen Opoku Mensah, Alexander Ayogyam, \\ Lydia Asare-Kyire, Zu Kwame Seyram Anthony, Researchers \\ Kumasi Polytechnic, Kumasi, Ghana \\ E-mail: wongnaaa@yahoo.com, steopo@yahoo.com, kingmulleraa@yahoo.com, \\ lydiaasarekyire@yahoo.com, zukwame@gmail.com
}

\begin{abstract}
The perishable nature of most agricultural produce and the concomitant need for effective marketing outlets carries along huge economic consequences, especially in developing countries like Ghana. This study examines the determinants of profit in tomato marketing in the Ashanti Region of Ghana. Cross-sectional data collected from a random sample of 200 tomato marketers consisting of 100 wholesalers and 100 retailers were analyzed using descriptive statistics and the multiple linear regression technique of the ordinary least squares. The results show that wholesalers have a higher margin of 99.7 percent, while the retailers have a margin of 75.4 percent. Labour cost, purchase price, transportation cost and selling price run through all the estimated regressions as determinants of marketing profit. The effects of these variables on marketing profit could raise public concern since they have implications on prices received by tomato producers and those paid by final consumers and therefore there is the need for the government to devise policies aimed at stabilizing the local currency.The results also call for policy efforts to completely eliminate illiteracy among tomato traders in Ghana especially in the Ashanti Region. Policies that could enable the retailers to increase their scale of operations are also advocated. Future researchers may also estimate the exact point in the age variable at which retail profit declines and possible antecedents.
\end{abstract}

\section{KEY WORDS}

Socioeconomics; Wholesalers; Retailers; Marketing; Profit; Tomato; Ghana.

Agriculture is an important sector in most developing countries. Increase in agricultural productivity depends heavily on its marketability. Efficient market does not only link sellers and buyers in reacting to current situations in supply and demand but rather has a dynamic role to play in stimulating consumption of outputs which are essential elements of economic development (Haruna et al, 2012). Katharina and Stefan (2011) reported that the concept of marketing subsumes a set of different innovative advertising instruments which aim at gaining a large effect with a small budget. Agricultural marketing is defined as the performance of all the activities involved in the flow of agricultural products and services from the initial points of agricultural production until they reach the hands of the ultimate consumers. It is interested in everything that happens to crops after they leave the farm gate; making decision, taking actions and bearing the responsibility of the action. Agricultural marketing also articulates all processes that take place from when the farmer plans to meet specified demands and market prospects to when the produce finally gets it to the consumers (Haruna et al, 2012).

Aminu (2009) pointed out that in a typical vegetable marketing, even though the marketing of vegetable crops does not require much capital, it essentially requires experience and good rapport with the commission agents and farmers. Olukosi and Isitor (2004) explained that the marketing task involves transferring goods from producers to consumers. It is the marketing function that ensures that consumers acquire the product in the form, places and time desired. Marketing stimulates production, enterprise and specialization, hence resulting in an improved productivity of all sectors of the economy. As the economy of a nation grows, the gap between farmers and consumers widened and the task of marketing becomes more complex (Abbott, 1987). In a research conducted by Oladejo and Sanusi (2008), the net returns to marketing were affected by estimated marketing costs and selected personal characteristics of marketers. The authors further 
disclosed that the marketers in the study area were carrying out their distributing function using diverse channels revealing that $10.9 \%$ claimed to supply their wares in wholesales while the remaining $26.4 \%, 42.7 \%$ and $20 \%$ sell directly to the retailers, final consumers and processors/food vendors, respectively.

Tomatoes are important in the daily meal preparation since it can be eaten raw or cooked. Larger quantities are used to produce soups, juice and sauces, ketchups, purees and paste. The seeds which are extracted from the pulp and its residues contain $24 \%$ oil which is used for salad dressing and in the manufacturing of margarine and soap. The residual press cake is used as stock feed as well as fertilizer. In addition, vegetable such as tomato apart from being consumed at home also earns foreign exchange to the producer countries, due to exportation. (Sani et al., 2011; Singh, 2004).

A well developed marketing system is expected to complement the farm production effort towards the realization of its desirable goals through the provision of time, place, possession and form utilities. The production and the marketing system of tomato consist of a myriad of relationship and arrangements which are based on structure conduct-relationship paradigms at each marketing level, that is, from the producers to the consumers. In order to ensure a stable supply of tomato throughout the year, the market structure should first be considered in addition to examining how they are procured and disposed. This can best be achieved through a critical analysis of the factors influencing the profitability of tomato marketing (Haruna et al, 2012). Massaoud and Srinivass (2012) revealed that there is the tendency to increase producer's share in the consumer's price if the number of intermediaries is reduced and the government intervenes in order to organize and structure the marketing cooperative unions so that the farmer can use these unions as profitable channels to sell their produce.

Marketing functions are specialized activities performed in accomplishing the marketing process. These functions are broadly classified as follows: physical functions, exchange functions and facilitating functions. Most decisions on pricing, channels, storage, and transportation depends on the accurate information available. Kluwana et al (2011) reported that supply chain management requires integration of processes between supply chain members in all functional areas including sourcing, manufacturing and distribution. This barrier has been categorized into different levels: managerial, organizational, technological, individual, financial, social and cultural. However, Yayock et al (1998) classified the intermediaries associated with the marketing of farm produce into several categories viz; local and urban. The local traders live in the village and take their produce to the market and then sell collections in village markets, either through village retailers or directly to consumers while the urban traders on the other hand purchase farm produce in rural markets from retailers or directly from farmers, and transport the produce to other markets or to urban centres for sale and their purchases are larger than the local traders. Retailers generally purchase produce from wholesalers and sell to the consumers who buy in small quantities at a time. The functions performed by retailers of farm produce include: reducing produce to small units where relatively low-income consumers can easily afford or buy, buying and displaying produce for sale at places that are convenient to consumers and sorting, processing and repackaging produce to suit consumers' needs. The wholesalers are individuals who rent stalls in urban markets and handle large quantities of farm produce and perform marketing functions such as buying, storing and financing the exchange of produce. Marketing through wholesalers has important advantages. Firstly, wholesalers buy produce from farmers or local traders and sell to the retailers, to other wholesalers' domestic and foreign markets and to manufacturers and agricultural processors. Secondly, wholesalers often finance the movement of produce and invariably bear most of the marketing risks. In general, farmers who are able to sell their produce directly to wholesalers at the village markets have better chance of receiving higher prices than those who dispose of theirs through local traders to wholesalers. The transporter is another intermediary in the tomato marketing value chain. The transporter conveys farm produce from place to place by means of animal power and various types of motor vehicles (Haruna et al, 2012). 
Marketing costs are the actual expenses incurred in the process of marketing. Olukosi and Isitor (2004) revealed that the marketing costs are often measured in terms of middlemen which simply reflect the share of the consumers' income that is required to cover the costs incurred in the marketing process. The authors observed that as more and more costly services are added, the farmer's share of expected returns will be reduced. However, the authors listed the marketing costs to include: costs of assembling, distribution, transportation, handling, packaging, taxes and levies. Marketing margin is the difference between the price paid by consumers and the purchase price. Differences in price are usually made up of margins taken by the wholesalers and retailers in addition to transport and other charges. Marketing margins could be described as the price paid for the collection of marketing services rendered by marketing agencies in the process of marketing the farm products. The size of the marketing margin is sometimes influenced by the degree of processing of the commodity in question, its bulkiness and unit values as well as perishability (Haruna et al, 2012).

Amongst the myriad of problems confronting agricultural production in Ghana, poor post-harvest handling practices has been fingered as a major culprit. For instance, Echebiri and Mejeha (2004) observed that poor storage and marketing facilities have further compounded the problems of low resource productivity and efficiency, which were reported by scholars like Ohajianya and Onyenweaku (2002) and Nnadozie and Nwaru (2005). An efficient marketing system ensures that the supply of goods, even those that are seasonal, is all year round, with little variation in prices, which can be attributed to high cost of storage; a situation which makes both the producers and consumers better off (Adegeye and Dittoh, 1982). Khols and Uhl (1985) observed that the perishable nature of agricultural products resulted in urgency in the marketing of these products. Marketing of food items is of great importance because domestic food security is closely related to it. The problem of food insecurity is made worse by the rising prices of staple foods, a large percentage of which arises through the operation of the price mechanism. However, Abbot (1957) and Obasi (2008) noted that serious inefficiencies characterized the operation of the marketing system in most developing countries as a result of so many socioeconomic, political, and other constraints militating against marketing efficiency. For instance, Echebiri and Mejeha (2004) opined that unpredictable fluctuations in the prices of various food products have become a common feature in the nation's economy; a situation that has led to the consumers of agricultural products paying so much while the producers receive lower prices. Moro (1994) noted that in the marketing of food products, the wholesalers and retailers exercised strong economic power in price determination and that this was responsible for wide variations in their mark-ups and unpredictable fluctuations in the prices of foodstuffs.

The current study specifically undertook an economic analysis of wholesale and retail tomato marketing in the Ashanti Region of Ghana by describing the socioeconomic characteristics of tomato marketers and also quantifying the effects of the factors that influence wholesale and retail profit.

\section{MATERIALS AND METHODS}

Study area. The Ashanti Region has an approximate area of 24,389 square kilometers of which $1,463,340$ hectares $(60 \%)$ are arable with $1,181,788$ hectares $(81 \%)$ currently under cultivation and it is located between longitude $0^{0} 15$ » and $2^{0} 25$ » West and Latitude $5^{\circ} 50$ » and $7^{0} 40$ » North. It shares boundaries with the Brong Ahafo region to the North, Western Region to the West, Central Region to the South and Eastern and Volta Regions to the East (MOFA, 2011). The current population is estimated at about $4,780,380$ with a growth rate of $2.7 \%$ per year (Ghana Statistical Service, 2012).

Data Collection. Only tomato markets were considered for this research. A total of five markets were selected out of which two were urban markets and the rest rural. The rural markets were Akumadan, Afrancho and Offinso and the urban markets were Kumasi Central Market and Asafo Market, all in Kumasi. In each market, tomato sellers were delineated into retailers and wholesalers. The list of each of these categories of sellers in each market 
formed the frame from which a simple random sample of 20 wholesalers and 20 retailers were chosen. In all, a total of 200 respondents were chosen for detailed study. Primary data was collected using a set of well-structured questionnaires and personal observations. Pieces of information were collected on the socio-economic characteristics like the educational background, the age, the sex and the household size of the respondents. Other variables on which data were collected were the costs of labour and transportation, purchase and selling prices per box of tomatoes, and quantity of tomatoes purchased for sale.

Analytical Framework. Descriptive statistics in the form of frequencies and percentages were used to describe the socioeconomic characteristics of the respondents while the multiple linear regression of the Ordinary Least Squares was used to analyze the factors influencing profit for wholesalers and retailers, separately and pooled. Marketing margins of the respondents were also calculated using the formula:

$$
\text { Marketing Margin }=\frac{\text { Selling Price }- \text { Purchase Price }}{\text { Selling Price }} \times 100
$$

The empirical model for the multiple linear regression model was also specified as:

$$
\begin{gathered}
\text { PROF }=\beta_{0}+\beta_{1} \text { AGE }+\beta_{2} \text { AGE }^{2}+\beta_{3} \text { SEX }+\beta_{4} \text { HSIZE }+\beta_{5} \text { EDU }+\beta_{6} \text { LABC }+\beta_{7} \text { PURCPR } \\
+\beta_{8} \text { QPURC }+\beta_{9} \text { TRANS }+\beta_{10} \text { SELPR }+\varepsilon_{\mathrm{i}}
\end{gathered}
$$

Where PROF $=$ Total marketing profit (measured in Ghana cedis) and is derived as:

$$
\text { Marketing Profit }=\text { Total Marketing Revenue }- \text { Total Marketing Cost }
$$

AGE = Age of respondent (measured in years). Age is expected to have a positive effect on the marketing profit of tomato wholesalers and retailers up to some point, followed by a negative effect subsequently (a quadratic function). This explains why age and the square of age are also included in the model as explanatory variables likely to significantly affect profit.

$\mathrm{EDU}=$ Educational level of tomato trader (measured in number of years of schooling). Education is expected to have a positive impact on the profit gained by tomato marketers, hence its inclusion in the model.

SEX $=$ Gender (measured as a dummy, 1 for male and 0 for female). The study wanted to know whether sex in any way affects the profit gained by tomato traders in Ashanti Region of Ghana, hence the inclusion of sex as an explanatory variable in the model.

HSIZE = Household size (measured as number of people under tomato trader's care). It is expected to have a positive impact on the profit gained by traders in Ashanti Region since it could serve as a source of family labour (Babalola et al, 2010) which would reduce the cost of labour that would be incurred.

$\mathrm{LABC}=$ Labour cost incurred by tomato traders (measured in Ghana cedis). It adds to the cost incurred by the trader and therefore it is expected to have a negative effect on tomato traders' profits.

PURCP = Purchase price of tomatoes (measured in Ghana cedis). This is the price at which a box of tomatoes is sold at the farm gate. It adds to the cost incurred by the trader and therefore it is expected to have a negative effect on tomato traders' profits.

QPURC = Quantity of tomatoes bought for sale (measured in kilogramme). The quantity of tomatoes that a marketer handles defines his/her scale of business operation. Ceteris paribus, the higher this scale, the higher the marketing profit because of possible economies of scale. Therefore quantity of tomatoes bought for sale is expected to have a positive effect on marketing profit.

TRANS = Cost of transportation (measured in Ghana cedis). It adds to the cost incurred by the trader and therefore it is expected to have a negative effect on tomato traders' profits. 
SELPR = Selling price of tomatoes (measured in Ghana cedis). Higher selling prices of tomatoes benefit tomato traders and therefore this variable is expected to positively affect marketing profit.

$\varepsilon_{\mathrm{i}}=$ is the error term assumed to fulfill all the assumptions of the classical linear regression model.

\section{RESULTS AND DISCUSSION}

Gender Distribution of Tomato Traders. The results show that $17 \%$ of the sampled tomato wholesalers were males and $83 \%$ were females (table 1). This means that most tomato wholesalers in Ashanti Region of Ghana were females. Table 1 also shows that $29 \%$ of the sampled tomato retailers were males and $71 \%$ were females. This also means that most tomato retailers in Ashanti Region of Ghana are females. The aforementioned results follow a particular pattern and could imply that even though both men and women can take tomato marketing as a business and a source of employment, tomato marketing is a clear female dominated business. However, the results of this study hold a contrary view to what was done by Haruna et al (2012) in Bauchi State, Nigeria which found that majority $(88 \%)$ of the fresh tomato marketers were men while only $12 \%$ were women.

Table 1 - Gender distribution of tomato traders

\begin{tabular}{|l|c|c|c|c|}
\hline \multicolumn{1}{|c|}{ Sex } & \multicolumn{2}{|c|}{ Wholesalers } & \multicolumn{2}{c|}{ Retailers } \\
\hline Male & Frequency & Percentage & Frequency & Percentage \\
\hline Female & 17 & 17 & 29 & 29 \\
\hline Total & 83 & 83 & 71 & 71 \\
\hline
\end{tabular}

Source: Field Survey Data 2013.

Age Distribution of Tomato Traders. The results of the study show that a greater percentage of tomato wholesalers in Ashanti Region of Ghana $(30 \%)$ are within the age brackets of 31-40 years (table 2). Table 2 also indicates that $5 \%$ of the wholesalers are below twenty (20) years while $25 \%$ of them are between the ages of twenty (20) and thirty (30) years. Only $4 \%$ of the wholesalers are above 60 years, an indication of active youth involvement in tomato marketing activities which enhances a sustained ready market for tomato producers in the region. The presence of a large number of youth engaged in tomato marketing would offer tomato farmers some level of market options and agents to supply their produce to.

Table 2 - Age distribution of tomato traders

\begin{tabular}{|c|c|c|c|c|}
\hline \multicolumn{1}{|c|}{ Age } & \multicolumn{2}{|c|}{ Wholesalers } & \multicolumn{2}{c|}{ Retailers } \\
\hline Below 20 & Frequency & Percentage & Frequency & 2 \\
\hline $20-30$ & 5 & 5 & 17 & 17 \\
\hline $31-40$ & 25 & 25 & 23 & 23 \\
\hline $41-50$ & 30 & 30 & 28 & 22 \\
\hline $51-60$ & 23 & 23 & 22 & 8 \\
\hline$>60 \quad$ Total & 13 & 13 & 8 & 100 \\
\hline
\end{tabular}

Source: Field Survey Data 2013.

Table 2 also reveals that a greater percentage of tomato retailers $(28 \%)$ are between $41-50$ years while $2 \%$ are below 20 years. Also, $17 \%$ of them are between the ages of twenty (20) and thirty (30) years. It is deduced from the results in table 2 that about $70 \%$ of retailers in Ashanti Region of Ghana are below 50 years. This is good news for Ghana, especially the Ashanti Region since there will be a sustained boosting of wholesale activities resulting from demand for wholesale products by retailers. Many people will therefore be attracted into the 
tomato wholesaling business because of the sustained presence of retailers thereby creating jobs for these people. The aforementioned results corroborate those of Haruna et al (2012) who found that fresh tomato marketers are relatively young and active to engage in marketing.

Educational Level of Tomato Traders. Table 3 summarizes the educational status of tomato wholesalers and retailers in Ashanti Region of Ghana. It can be shown that $35 \%$ of tomato wholesalers in the study area were complete illiterates while the remaining $65 \%$ had some form of education ranging from primary (25\%), Middle/Junior High School $(31 \%)$, Senior High School (8\%) and Post Secondary/Tertiary (1\%).

Table 3 - Educational level of tomato traders

\begin{tabular}{|l|c|c|c|c|}
\hline \multirow{2}{*}{ Educational level } & \multicolumn{2}{c|}{ Wholesalers } & \multicolumn{2}{c|}{ Retailers } \\
\cline { 2 - 5 } & Frequency & Percentage & Frequency & Percentage \\
\hline Illiterate & 35 & 35 & 26 & 26 \\
\hline Primary & 25 & 25 & 40 & 40 \\
\hline Middle School/JSS/JHS & 31 & 31 & 26 & 26 \\
\hline Secondary/Vocational/Technical & 8 & 8 & 8 & 8 \\
\hline Post Secondary/Tertiary & 1 & 1 & 0 & 0 \\
\hline Total & 100 & 100 & 100 & 100 \\
\hline
\end{tabular}

Source: Field Survey Data 2013.

For the retailers, the results of the study in table 3 shows that $26 \%$ of tomato retailers in Ashanti Region of Ghana are illiterates, $40 \%$ had a maximum of primary education while $26 \%$ of them were also educated up to the Middle or Junior High School level.

Coincidentally, the number of retailers who had a maximum of Secondary/Vocational/Technical Education was found to be equal to those of wholesalers $(8 \%)$. None of the retailers had post secondary or tertiary education. The results signify that the respondents are fairly educated which is of significant importance in their marketing decision-making process. This finding is in agreement with that of Aighemi and Lyonga (1989) which revealed that literate traders adopt new marketing ideas faster than illiterate ones and would find it relatively easier in their dealings with people more especially in the exchange process.

Household Size of Tomato Traders. Most of the tomato wholesalers (52\%) sampled for the study have a family size of $2-5$ members while $48 \%$ also have a family size of between 6 10 members and none of them has more than 10 members in his/her family (table 4). Table 4 also presents similar results for the retailers with $63 \%$ of them having a household size of $2-5$ members while $37 \%$ have between 6 and 10 members. Here too none of the retailers has more than ten in a family. Large household sizes could be beneficial to tomato traders since family labour would be available to reduce labour costs for both wholesalers and retailers. However, it also highlights the likelihood of high poverty level among the marketing households (Akinbile and Ndaghu, 2005; Babalola and Agbola, 2008).

Table 4 - Household size of tomato traders

\begin{tabular}{|c|c|c|c|c|}
\hline \multirow{2}{*}{ Household Size } & \multicolumn{2}{|c|}{ Wholesalers } & \multicolumn{2}{c|}{ Retailers } \\
\cline { 2 - 5 } & Frequency & Percentage & Frequency & Percentage \\
\hline $2-5$ & 52 & 52 & 63 & 63 \\
\hline $6-10$ & 48 & 48 & 37 & 37 \\
\hline$>10$ & 0 & 0 & 0 & 0 \\
\hline Total & 100 & 100 & 100 & 100 \\
\hline
\end{tabular}

Source: Field Survey Data 2013.

Marketing Margin of Tomato Traders. Table 5 summarizes and presents the marketing margin for the wholesalers and retailers. This table indicates that the wholesalers have a higher margin of 99.7 percent, while the retailers have a margin of 75.4 percent. This result is in line with those of Obasi (2008), who reported a higher gross marketing margin for the 
wholesalers than the retailers in rice marketing in Abia State of Nigeria. Similarly, Echebiri and Mejeha (2004) reported higher gross and net marketing margins for the wholesalers in Abia State, Nigeria. They reported a gross margin of 12.31 percent and 7.94 percent for the wholesalers and retailers, respectively. However, Scarborough and Kydd (1992) opined that five percent and ten percent marketing margins are acceptable for storable and perishable goods, respectively. This implies that the margins received by the wholesalers and retailers in the study area are acceptable. The marketing margin for the retailers $(75.4 \%)$ also agrees with the results of Nwaru et al (2011) who obtained a marketing margin of $74 \%$ in their study of socioeconomic determinants of profit in wholesale and retail banana marketing in Umuahia agricultural zone of Abia state, Nigeria.

Table 5 - Marketing margin of tomato traders

\begin{tabular}{|c|c|c|c|}
\hline Trader & Average Purchase Price $(\mathrm{Gh} \phi)$ & $\begin{array}{c}\text { Average Selling } \\
\text { Price }(\mathrm{Gh} \phi)\end{array}$ & Marketing Margin (\%) \\
\hline Wholesaler & 99.4 & 31602 & 99.7 \\
\hline Retailer & 192.51 & 781.3 & 75.4 \\
\hline
\end{tabular}

Source: Field Survey Data 2013.

Factors Influencing Profit in Wholesale and Retail Tomato Marketing. The summary of the parameter estimates for the factors that affect profit at the tomato wholesale level is presented in Table 6. The model, with an $\mathrm{R}^{2}$ value of 0.999672 shows that the independent variables account for 99.9 percent of the variation in the wholesale profit. The estimated Fstatistic (27095.11) is significant at 1 percent, indicating that the model is adequate for use in further analysis. The results show that the level of formal education, cost of labour for wholesaling activities, purchase price, cost of transportation and the selling price are the significant determinants of profit for the tomato wholesalers. Whereas education and selling price are positively related to wholesale profit, purchase price of tomatoes, cost of transportation and labour cost for wholesaling activities are negatively related to it. These results conform to a priori expectations. Increasing the level of formal education by one more year will increase wholesale profit by 4.18 and this is significant at $10 \%$. Obasi (2008) observed that better education of the marketers has advantages as it enlightens them on how best to strategize and to adapt to better marketing conditions. An increase in the selling price by one Ghana cedi will also improve the value of wholesale profit by 0.997 and this is highly significant at $1 \%$.

Table 6 - Estimated coefficients of determinants of profit for tomato traders

\begin{tabular}{|c|c|c|c|c|c|c|}
\hline \multirow{2}{*}{ Variables } & \multicolumn{2}{|c|}{ Wholesalers } & \multicolumn{2}{|c|}{ Retailers } & \multicolumn{2}{|c|}{ Pooled } \\
\hline & Coefficient & Prob. & Coefficient & Prob. & Coefficient & Prob. \\
\hline C & 26.10849 & 0.9320 & -8.405711 & 0.1764 & 3.279458 & 0.9776 \\
\hline AGE & -23.31297 & 0.8394 & $0.706264^{*}$ & 0.0690 & -13.45009 & 0.7964 \\
\hline $\mathrm{AGE}^{2}$ & -0.179662 & 0.9905 & $-0.038153^{*}$ & 0.0779 & -0.052822 & 0.9939 \\
\hline SEX & -59.16600 & 0.3546 & 0.714091 & 0.5891 & -24.40115 & 0.3972 \\
\hline HSIZE & 42.99730 & 0.3914 & 1.815205 & 0.1611 & 25.05585 & 0.3088 \\
\hline EDU & $4.183367^{*}$ & 0.0748 & 0.759365 & 0.2891 & $2.31447^{*}$ & 0.0585 \\
\hline LABC & $-1.517698^{* *}$ & 0.0147 & $-1.286570^{* * *}$ & 0.0000 & $-1.510967^{* * *}$ & 0.0001 \\
\hline PURCP & $-0.957370^{* *}$ & 0.0360 & $-0.995751^{* * *}$ & 0.0000 & $-0.901862^{* * *}$ & 0.0012 \\
\hline QPURC & 0.733284 & 0.3617 & $1.254062^{* *}$ & 0.0209 & $0.57625^{* *}$ & 0.0451 \\
\hline TRANS & $-0.979754^{* * *}$ & 0.0000 & $-0.882365^{\star * *}$ & 0.0000 & $-0.978415^{* * *}$ & 0.0000 \\
\hline SELPR & $0.996898^{* * *}$ & 0.0000 & $0.998992^{\star \star \star}$ & 0.0000 & $0.997629^{* * *}$ & 0.0000 \\
\hline $\mathrm{R}^{2}$ & 0.999672 & \multirow{3}{*}{-} & 0.999879 & \multirow{3}{*}{ - } & 0.999917 & \multirow{3}{*}{ - } \\
\hline F-STAT & 27095.11 & & 93869.91 & & 227665.6 & \\
\hline PROB(F-STAT) & 0.000000 & & 0.000000 & & 0.000000 & \\
\hline
\end{tabular}

Source: Field Survey Data 2013.

Note: $\left({ }^{* * *}\right)$ Indicates significance at the $1 \%$ level. $\left({ }^{* *}\right)$ Indicates significance at the $5 \%$ level.

$\left(^{*}\right)$ indicates significance at the $10 \%$ level 
Conversely, an increase in each of purchase price of tomatoes, cost of transportation and labour cost for wholesale activities by one Ghana cedi would cause wholesale profit to decline by factors of 0.96 (significant at 5\%), 0.98 (significant at 1\%) and 1.52 (significant at $5 \%$ ) respectively (table 6 ).

The summary of the parameter estimates for the factors that affect profit at the retail level is also presented in Table 6 . The model, with an $\mathrm{R}^{2}$ value of 0.999879 shows that the independent variables account for 99.9 percent of the variation in the retail profit. The estimated F-statistic (27095.11) is significant at 1 percent, indicating that the model is adequate for use in further analysis.

The age of the retailers has a coefficient that is significant at 10 percent level and positive while the square of age variable has a negative coefficient (also significant at 10\%), indicating that retail marketing profit initially increases with an increase in age up to a certain age and decreases as the age of the marketer increases beyond that age (table 6 ). Before a retailer reaches the maximum age, increasing his/her age by one more year will add to retail profit by a factor of 0.71 whereas after the maximum age, ageing rather declines retail profit by a factor of 0.038 . The results agree with a prior expectations and Nwaru and Iwuji (2005), who reported a negative, although insignificant, relationship between the age and gross margins in plantain marketing in Imo State, Nigeria. Nwaru et al (2011) also had similar results. Nwaru (2004 and 2005) indicated that entrepreneurship dwindles as the age of the entrepreneur increases. The studies attributed this to the fact that the innovativeness and optimism of the entrepreneur and his mental capacity to cope with the challenges of his business activities as well as his mental and physical abilities to do manual work decrease with age.

The coefficient of the quantity of tomatoes handled by a retailer was significant at 5 percent and positively related to profit. This is expected and agrees with the report from Nwaru and Iwuji (2005) and Nwaru et al (2011). An increase in the quantity of tomatoes purchased by one kilogramme has the effect of increasing retail profit by 1.25 (table 6). The quantity of tomatoes that a retailer handles defines his scale of business operation. Ceteris paribus, the higher this scale, the higher the marketing profit because of possible economies of scale. Therefore, policies that could enable the retailers to increase their scale of operations are advocated. This could be achieved amongst others through reorientation programmes aimed at changing their capacity for business initiatives, micro credit, and other infrastructural provisioning (Nwaru et al, 2011).

The purchase price of tomatoes has a coefficient that is significant at $1 \%$ and it is negative. A rise in the purchase price of tomatoes by one Ghana cedi has the effect of decreasing retail profit by 0.996 . On the other hand, the selling price of tomatoes per unit has a coefficient that is significant at $1 \%$ and positive. A one Ghana cedi increase in the selling price of tomatoes will cause an improvement in retail profit by 0.999 . The aforementioned results are expected. If the purchase price per unit increases, the profit is bound to decrease. Conversely, if the selling price per unit increases, the profit is bound to increase. Echebiri and Mejeha (2004) observed that unpredictable fluctuations in the prices of various food products have become a common feature in West African economies. A practical implication of this situation is that the consumers of agricultural products pay so much, while the producers receive relatively low prices; a situation that has remained a binding clog to the wheels of agricultural development in most West African states especially Ghana.

The estimated determinants of the profit function for all the sampled tomato sellers in Ashanti Region of Ghana (pooled wholesalers and retailers) are also summarized and presented in table 6 . The model, with an $\mathrm{R}^{2}$ value of 0.999917 shows that the independent variables account for 99.9 percent of the variations in the retail profit. The estimated $\mathrm{F}$ statistic (22766.6) is significant at 1 percent, indicating that the model is adequate for use in further analysis. Table 6 shows that the level of formal education, the quantity of tomatoes handled, costs of transportation and labour and the purchase and selling prices of tomato are the statistically significant determinants of the profit from tomato sales.

Their level of formal education is significant at 10 percent and positively signed as expected. Additional year of formal education received by a tomato trader will increase 
his/her marketing profit by a factor of 2.31. Education helps to unlock the natural talents and inherent enterprising qualities of the marketers (Nwaru, 2004); making them more skilled and amenable to risk taking and change than the non-educated people. The quantity of tomatoes handled by a trader is significant at $5 \%$ and positively signed as expected. A one kilogramme increase in the quantity of tomatoes handled by a trader has the effect of increasing marketing profit by a factor of 0.58 . The purchase and selling prices of tomatoes are other important statistically significant determinants of profit from tomato sales; each maintained the right a priori sign. A rise in the purchase price of tomatoes handled, by one Ghana cedi will cause a decline in marketing profit by a factor of 0.902 (significant at $1 \%$ ). Similarly, a cedi increase in the selling price of tomato traded will improve marketing profit by a factor of 0.998 (also significant at $1 \%$ ).

\section{CONCLUSION}

The results show that even though both men and women can take tomato marketing as a business and a source of employment, tomato marketing is a clear female dominated business. The results also indicate active youth involvement in tomato marketing activities which enhances a sustained ready market for tomato producers in the region. Retail activities will also be boosted. Many people will therefore be attracted into the tomato producing and wholesaling business because of the sustained presence of wholesalers and retailers thereby creating jobs and incomes for the market participants. The results further show that the respondents are fairly educated which is of significant importance in their marketing decision-making process. This is because literate traders adopt new marketing ideas faster than illiterate ones and would find it relatively easier in their dealings with people more especially in the exchange process. However some of the traders were found to be illiterates. Also, none of the retailers had post secondary or tertiary education.

The study reveals that wholesalers have a higher margin of 99.7 percent, while the retailers have a margin of 75.4 percent. It could therefore be concluded from this study that tomato marketing is profitable. Therefore, it could serve as a source of income and employment for the marketers. It could also be inferred from the study that for the wholesalers, level of formal education and the selling price of tomatoes are directly related to profit, while the cost of labour for wholesale activities, purchase price and cost of transportation are negatively related to it. For the retailers, quantity of tomatoes purchased and the selling price of tomatoes are significant and positively related to profit, while costs of labour and transportation as well as purchase price of tomatoes are negatively related to it. Age was initially positive for this regression but the square of age was negative, indicating a decline in profit after attaining a certain age. For the pooled data, education, quantity of tomatoes handled, and selling price per unit are significant and positively related to profit, while costs of labour and transportation and purchase price of tomatoes are negatively related to it.

The results call for policy efforts to completely eliminate illiteracy among tomato traders in Ghana especially in the Ashanti Region. Such policies should enable the marketers to acquire more education through adult education, seminars, workshops, etc. and should be targeted more at the younger marketers. This should enable them to increase the quantity of tomatoes that they handle. Labour cost, purchase price, transportation cost and selling price run through all the three regressions as determinants of marketing profit. The effects of these variables on marketing profit could raise public concern since they have implications on prices received by tomato producers and those paid by final consumers and therefore there is the need for the government to devise policies aimed at stabilizing the local currency. Policies that could enable the traders to increase their scale of operations are also advocated. Future researchers should also estimate the exact point in the age variable at which retail profit declines.

\section{REFERENCES}


1. Abbot, J. C. (1957). «Agricultural Products and Marketing in the Tropics». London: Longman Group Ltd.

2. Abbot, J. C. (1987). «Agricultural Marketing Enterprises in Developing World». Cambridge, U.K Cambridge University Press, pp.1440.

3. Adegeye, A. J. and Dittoh, J.S. (1982). «Essentials of Agricultural Economics». Ibadan: Impact Publishers Ltd.

4. Aighemi, B. A and Lyonga, S. N. (1989). «Tomato Production, storage and Marketing in Cameroon». Tropical Root Crops, proceedings of the 9th symposium of International Society for Tropical root crops. Akoroda, M.O and Arene, O.B. (eds) Accra, Ghana. Pp $377-382$.

5. Akinbile, L. A and Ndaghu, A. A. T. (2005). «Poverty Levels and Poverty Alleviating Strategies of Farm Families in Michika LGA of Adamawa State». Nigeria Journal of Rural Economics and Development. 14(2) 101-108.

6. Aminu, A. (2009). «Framework for Agricultural Market Analysis: Theories and Application». Ahmadu Bello University Press Limited, Zaria. ISBN: 978-125-112-3, Pp184.

7. Babalola, D. A, Megbope, T. A, and Agbola, P.O (2008). «Post Harvest Losses in Pineapple Production: A Case Study Of Ado-Odo Otta Local Government Area Of Ogun State». Bowen Journal of Agriculture 5 (1\&2)55-062.

8. Babalola, D.A., Makinde, Y.O., Omonona, B.T., and Oyekanmi, M.O. (2010). «Determinants of Post harvest losses in tomato production: A case study of Imeko-Afon local government area of ogun state». Journal of Life and Physical Sciences, 3(2):14-18.

9. Echebiri, R.N. and Mejeha, R.O. (2004). "An Analysis of the Conduct and Efficiency of Garri Market in Umuahia area of Abia State, Nigeria». Journal of the Science of Agriculture, Food Technology and the Environment, 4, 85-91.

10. Ghana Statistical Service (2012). 2010 Population and Housing Census. Summary Report of Final Results. A Publication of the Ghana Statistical Service.

11. Haruna, U., Sani., M.H., Danwanka., H.A. and Adejo. (2012). Economic Analysis of Fresh Tomato Marketers in Bauchi Metropolis of Bauchi State, Nigeria». Nigerian Journal of Agriculture, Food and Environment, 8(3):1-8.

12. Katharina, H. and Stefan, H.( 2011). «Guerrilla Marketing: The Nature of Concept and Prepositions for further Research». Asian Journal of Marketing, 5(2):39-54.

13. Kohls, R. L. and Uhl, J. N. (1985). «Marketing of Agricultural Products». United States of America: Macmillan Publishing Company.

14. Kluwana, M. K., Mishra, P. K. and Singh, O. A. R. (2011). «Barriers to Information Sharing in Supply Chain of Manufacturing Industries». International Journal of Manufacturing Systems, 1(1):9-29.

15. Massaoud, K. and Srinivass, M. V. G. (2012). «Marketing Efficiency and Price Spread for Saffron in Iran». Trends in Agricultural Economics, 5(1):23-30.

16. Ministry of Food and Agriculture (MOFA).(2011). Agriculture in Ghana: Facts And Figures

17. Statistics, Research and Information Directorate (SRID).

18. Moro, R. S. (1994). «Agricultural Development and Food Marketing in the Developing Countries». Port Harcourt, Nigeria: Palm Unique Publishers Company Ltd.

19. Nnadozie, B.C. and Nwaru, J.C. (2005). «Measuring and Explaining Allocative Efficiency in Resource Use in Arable Crop Production in Abia State of Nigeria». In O.D. Ogisi, P.B. Okuneye, and W.J. Oyaide (Eds.), Economic Reforms and Management of Nigerian Agriculture (pp. 84 89). In proceedings of the 19th annual conference of the Farm Management Association of Nigeria, Delta State University, Delta State, Nigeria.

20. Nwaru, J.C. (2004). «Rural Credit Markets and Resource Use in Arable Crop Production in Imo State of Nigeria (Unpublished Doctorate Dissertation). Department of Agricultural Economics, Michael Okpara University of Agriculture, Umudike, Nigeria.

21. Nwaru, J. C. (2005). «Determinants of Farm and Off-Farm Incomes and Savings of Food Crop Farms in Imo State, Nigeria: Implications for Poverty Alleviation». The Nigerian Agricultural Journal, 36, $26-42$. 
22. Nwaru, J. C. \& Iwuji, O. (2005). «Marketing Margins and Their Determinants in Plantain Marketing in Owerri Agricultural Zone of Imo State, Nigeria». In A.M. Orheruata, S.O. Nwokoro, M.T. Ajayi, A.T. Adekunle, and G.N. Asumugha, Agricultural Rebirth for Improved Production in Nigeria (eds.), In proceedings of the $39^{\text {th }}$ Annual Conference of the Agricultural Society of Nigeria, University of Benin, Benin City, Nigeria, $385-387$.

23. Nwaru, J.C., Nwosu, A.C and Agommuo, V.C. (2011). "Socioeconomic Determinants of Profit in Wholesale and Retail Banana Marketing in Umuahia Agricultural Zone of Abia State, Nigeria». Journal of Sustainable Development in Africa. Vol 13, No. 1

24. Obasi, I.O. (2008). «Structure, Conduct and Performance of Rice Markets in Abia State, Nigeria». (Unpublished Master's Thesis), Michael Okpara University of Agriculture, Umudike, Nigeria.

25. Ohajianya, D.O. and Onyenweaku, C.E. (2002). «Farm Size and Relative Efficiency in Rice Production in Ebonyi State, Nigeria». Modeling, Simulation and Control Series D, 23(2), $1-16$.

26. Oladejo, J. A. and Sanusi W. A. (2008). Marketing Analysis of Plantain in Owo and Ose Local Government Areas of Ondo State, Nigeria. International Journal of Agricultural Economics and Rural Development, 1 (2): 93-101.

27. Olukosi J. O and Isitor, S. U. (2004). Introduction to Agricultural Marketing and Prices: Principles and Applications. LivingBooks Series/G.U. Publications.Abuja, FCT.

28. Sani, M. H., Haruna, U. and Jacob, L. J. (2011). «Effects of Agrochemicals Marketing on Output of Small-Scale Farmers in Zungur District of Bauchi State, Nigeria». In: Odedina, S. A., Osuntade, O. B., Adebayo, K., Awodun, M. O. and Fapohunda, O. O. (eds.). Policy and Agricultural Development in Nigeria: Challenges and Prospects. Proceedings of the 25th National Conference of Farm Management Association of Nigeria, held at the Federal College of Agriculture, Akure, 05th - 08th September, pg. 463-473.

29. Scarborough, V. and Kydd, J. (1992). «Economic Analysis of Agricultural Markets»: A Manual, Vol. 5. United Kingdom: Chatham.

30. Singh, B. R. (2004). "Constraints to Sustainable Crop Production in Semi Arid North West of Nigeria». The Nigerian Journal of Agricultural and Rural Management 7(1): 4062.

31. Yayock, J.Y., Lombin, G. and Owonobi, J. J. (1998). «Crop Science and Production in Warm Climates». Macmillan intermediate Agricultural Series. 